\title{
Participatory survey of citrus in the "Recôncavo Baiano region" with emphasis on the threat of huanglongbing
}

\author{
Gabriela Souza de Oliveira ${ }^{1}$, Marilene Fancelli ${ }^{2}$, \\ Suely Xavier de Brito Silva ${ }^{3}$, Sérgio Roberto Lemos de Carvalho ${ }^{4}$ \\ Abstract - Huanglongbing (HLB) is one of the most devastating diseases for citrus sector. In \\ Brazil, the state of Bahia is free of the disease, however it is on constant alert to prevent its \\ introduction. One of the main areas of citrus exploitation in the state is located in the Recôncavo \\ Baiano's identity territory and is characterized by family-based production. This study aimed \\ to perform a participative phytosanitary diagnosis with citrus growers from the "Recôncavo \\ Baiano" region, recording their perception regarding the HLB and its vector, Diaphorina citri. \\ The diagnosis, which featured 109 interviews, was carried out in five prominent cities in citrus \\ production (Cruz das Almas, Governador Mangabeira, Muritiba, Santo Antônio de Jesus and \\ São Felipe). The results showed that $70 \%$ of citrus growers never heard of the disease. It also \\ indicated that only $6 \%$ of farmers have technical assistance. Even with the tradition of citrus \\ farmers, the use of technologies is still limited. The presented results constitute an important \\ tool for phytosanitary defense, as it provides strategic information that enable the planning of \\ indispensable actions for preventing HLB entry in this territory, and also to minimize its negative \\ impacts, contributing with the maintenance of the citrus production chain. \\ Index terms: Family-based farming, Phytosanitary defense, Diaphorina citri, Greening.

\section{Levantamento participativo da citricultura no Recôncavo Baiano com ênfase na ameaça do huanglongbing}

Corresponding author:
marilene.fancelli@embrapa.br

Received: December 31, 2020 Accepted: March 25, 2021

Copyright: All the contents of this journal, except where otherwise noted, is licensed under a Creative Commons Attribution License.

\section{(cc) $\mathbf{E Y}$}

Resumo - O Huanglongbing (HLB) é uma das doenças mais devastadoras para o setor citrícola. O Estado da Bahia é considerado livre da doença, porém encontra-se em constante alerta para impedir sua introdução. Um dos principais polos de citricultura no estado está localizado no território de identidade do Recôncavo Baiano e caracteriza-se pela produção de base familiar. Este trabalho objetivou realizar um diagnóstico fitossanitário participativo com citricultores do Recôncavo Baiano, registrando a percepção dos mesmos em relação ao HLB e seu vetor, o psilídeo Diaphorina citri. O diagnóstico, que contou com 109 entrevistas, foi realizado em cinco municípios de destaque na produção citrícola (Cruz das Almas, Governador Mangabeira, Muritiba, Santo Antônio de Jesus e São Felipe). Os resultados apontaram que 70\% dos citricultores nunca ouviram falar da doença. Também indicou que apenas $6 \%$ dos agricultores contam com assistência técnica. Mesmo com a tradição dos agricultores no cultivo de citros, identificou-se que o uso de tecnologias ainda é muito restrito. Os resultados apresentados constituem-se em uma importante ferramenta para a defesa fitossanitária, pois fornecem informações estratégicas ao planejamento de ações indispensáveis para prevenir a entrada do HLB no território e para minimizar seus impactos, contribuindo para a manutenção da cadeia produtiva de citros.

Termos para indexação: Agricultura familiar, Defesa fitossanitária, Diaphorina citri, Greening.

\footnotetext{
${ }^{1}$ MSc in Agricultural Defense, Universidade Federal do Recôncavo da Bahia, UFRB, Cruz das Almas - BA, Brazil. E-mail: gaby_soliveira@ yahoo.com.br ${ }^{\text {(ORCID } 0000-0002-6633-7007)}$

${ }^{2} \mathrm{PhD}$, Researcher at Embrapa Mandioca e Fruticultura, Cruz das Almas - BA, Brazil. E-mail: marilene.fancelli@embrapa.br(ORCID 0000-00025004-1236)

${ }^{3} \mathrm{PhD}$, Agência Estadual de Defesa Agropecuária da Bahia, ADAB, Salvador - BA, Brazil. E-mail: suely.xavier@adab.ba.gov.br ${ }^{\text {(ORCID } 0000-}$ 0003-3413-1490)

${ }^{4} \mathrm{PhD}$, Professor at Secretaria de Educação do Estado da Bahia, SEEB, Cruz das Almas - BA, Brazil. E-mail: sergiorobertolc@hotmail.com (ORCID 0000-0003-3936-1113)
} 


\section{Introduction}

In Brazil, the production of citrus contributes directly to the economy development in the country. This sector exerts great influence in the generation of jobs, capital and income, in value aggregation and also, in the regional expansion (ZULIAN et al., 2013).

In the state of Bahia, the citriculture presents high socioeconomic relevance, being explored, in most part, by family farmers, although the majority of the cultivated area is also concentrated in large and medium producers, similarity of what is reported for the state of São Paulo (GIRARDI et al., 2015). However, regarding the productivity, the state could present better production indexes, and the yield of the orchards from Bahia are much lower than that presented by those from São Paulo (REZENDE, 2011; SHIBATA et al., 2014). In 2019, the productivity of Bahia orange orchards was of 11.255 kg.ha ${ }^{-1}$, while the São Paulo ones were of $35.145 \mathrm{~kg} \cdot \mathrm{ha}^{-1}$ (IBGE, 2018). For lemons and tangerines, the yields were of $11.882 \mathrm{~kg} \cdot \mathrm{ha}^{-1}$ and $9.000 \mathrm{~kg} \cdot \mathrm{ha}^{-1}$, in Bahia and of 36.559 kg.ha- ${ }^{-1}$ and $29.953 \mathrm{~kg} \cdot \mathrm{ha}^{-1}$, in São Paulo, respectively (IBGE, 2018).

The citrus exploration in the Recôncavo Baiano region is practiced by small producers, with areas lower than ten hectares and low productivity (OLIVEIRA et al., 2013; SHIBATA et al., 2014). According to Girardi et al. (2015), it is an activity that is in decline in some municipalities such as Cruz das Almas, Santo Antonio de Jesus, Sapeaçu, Cabaceiras do Paraguaçu, Governador Mangabeira, Conceição do Almeida, São Felipe, Muritiba, Castro Alves and Maragogipe, due to the disorganization of the local citrus growers, the low technological level adopted in conducting orchards and to the homogeneity of canopy and rootstocks varieties. However, it is still an important economic activity, contributing directly in the generation of employment and income (OLIVEIRA et al., 2013; SHIBATA et al., 2014) and the main production pole of citrus seedlings of the state (GIRARDI et al., 2015).

Due to the sharp occurrence of pests and diseases in the orchards, the productivity of the crops in Brazil is often compromised. As an option to maintain the productive potential, it is common practice to intensify the use of pesticides in the production areas (FERREIRA, 2014). With the introduction of the Huanglongbing (HLB) or greening, sprayings for control of the vector have intensified, mainly during the vegetative flows of the plant, coincident with the emission of new springs, critical periods to the transmission of the bacteria by vector insect, Diaphorina citri Kuwayama, 1908 (Hemiptera: Psyllidae) (DE CARLI et al., 2018).

Taking into account the diseases that occur in citrus, the HLB, in the present day, is pointed as the most serious problem in citrus crop in Brazil and in the world and represents a high risk to the sustainability of the agribusiness (BOVÉ, 2006; HALL et al., 2012;
GRAFTON-CARDWELL et al., 2013). The HLB progresses quickly, limiting the production, and, consequently, increasing its costs (OLIVEIRA et al., 2013; PALMIERI et al., 2016; SULZBACH et al., 2017; 2018).

The first record of the HLB in Brazil was in 2004 and, since January 2005 to June 2019, around 55.5 million plants were eradicated in the state of São Paulo (CDA, 2019). In the Brazilian territory, the disease is associated with the bacteria Candidatus Liberibacter asiaticus and $\mathrm{Ca}$. L. americanus, which have as insect vector the psyllid D. citri (GRAÇA et al., 2016). Besides the state of São Paulo, the main citrus producer in Brazil, the HLB is found in Minas Gerais, Paraná and Mato Grosso do Sul (BASSANEZI et al., 2020).

According to Belasque Junior et al. (2009), the disease does not cause the death of plants, however, the economic impacts are proportioned by the reduction of the production, with loss in the quality of the fruits and early fall. It is reported that orchards affected by the disease can become economically unviable in the period of seven to ten years after the finding of the first symptomatic plant, in case of not adopting containment measures of the disease (BELASQUE JUNIOR et al., 2009). However, in young orchards, Gottwald et al. (2007) consider that this time interval is still lower, on average of four to five years.

The state of Bahia is recognized by the Ministry of Agriculture, Livestock and Supply as free area of HLB (OLIVEIRA et al., 2013; SANCHES et al., 2018). However, in view of the presence of $D$. citri in the state and considering the proximity of infected citrus orchards in states bordering Bahia, such as Minas Gerais, the introduction of the disease in the region is an imminent risk (OLIVEIRA et al., 2013; SANCHES et al., 2018). In addition, the transport of citrus seedlings or orange jasmine, Murraya paniculata (L.) Jack, infected with the bacterium $\mathrm{Ca}$. Liberibacter and also infested with psyllid with the bacteria is a potential risk to the introduction of HLB in Bahia (OLIVEIRA et al., 2013).

Besides highly favorable to the development of $D$. citri, the orange jasmine can also be considered a host of $\mathrm{Ca}$. Liberibacter asiaticus, but in titration rates much lower than in Citrus species (DAMSTEEGT et al., 2010; LOPES et al., 2010). It is a very common ornamental plant in the Recôncavo Baiano region, and in four municipalities (Sapeaçu, Cruz of Almas, Governador Mangabeira and Muritiba), Laranjeira et al. (2011) verified the association of the citrus production with neighborhood of M. paniculata plants. Regarding the varieties, according to Grafton-Cardwell et al. (2013) and Bassanezi et al. (2020), all citrus species used as rootstock and canopy are susceptible to the HLB, not knowing varieties resistant to the disease. 
It is estimated that the losses resulting from the entry and dissemination of the HLB in the state of Bahia are of the order of $\mathrm{R} \$ 1.8$ billion in a horizon of 20 years in the absence of disease control (OLIVEIRA et al., 2013). As already mentioned, the Bahia citriculture, particularly that established in the Recôncavo Baiano region, is practiced by small farmers, who, as example of the small and medium farmers in São Paulo, would suffer the impacts of the HLB in a more significant way (BASSANEZI et al., 2020), due to the non-adoption of preventive and management measures of the insect vector and of the disease (OLIVEIRA et al., 2018). The difficulty in accessing technical information, the lack of knowledge of the disease symptoms and the low level of technification in its properties, contribute to the severity of this picture (OLIVEIRA et al., 2013; 2018).

Another factor that contributes to the large impact of the HLB on small properties is related to the highest proportion among the edges and the central area of the orchard, compared with extensive areas ("edge effect") (BASSANEZI et al., 2010; 2020). This fact explains why small orchards (dozens of hectares) are more exposed to the entry of adults of $D$. citri infective from neighboring areas (primary infection), culminating in the higher incidence of plants infected by the HLB (BASSANEZI et al., 2010; 2020). This situation is also verified in orange orchards in the southern region of the state of Minas Gerais, in which small producers predominate, in contrast to those of the Mineiro Triangle, basically composed of medium and large producers (ALVES et al., 2020).
Thus, the use of phytosanitary diagnoses is of great importance, as it allows identifying scenarios that offer withstand to the planning of citrus activity, aiming to the implementation of plant defense actions, both preventive and eventually, of control.

The objective of this study was to perform a participatory phytosanitary diagnosis with family citrus growers of the Recôncavo Baiano's identity territory, as well as establish the degree of knowledge of citrus producers on HLB and its vector.

\section{Material and Methods}

Characterization of the study area

The territory chosen for the study was the Recôncavo Baiano region, which is formed by 19 municipalities: Cabaceiras do Paraguaçu, Cachoeira, Castro Alves, Conceição do Almeida, Cruz das Almas, Dom Macêdo Costa, Governador Mangabeira, Maragogipe, Muniz Ferreira, Muritiba, Nazaré, Salinas da Margarida, Santo Amaro, Santo Antônio de Jesus, São Felipe, São Félix, Sapeaçu, Saubara and Varzedo (CODETER, 2017) (Figure 1).

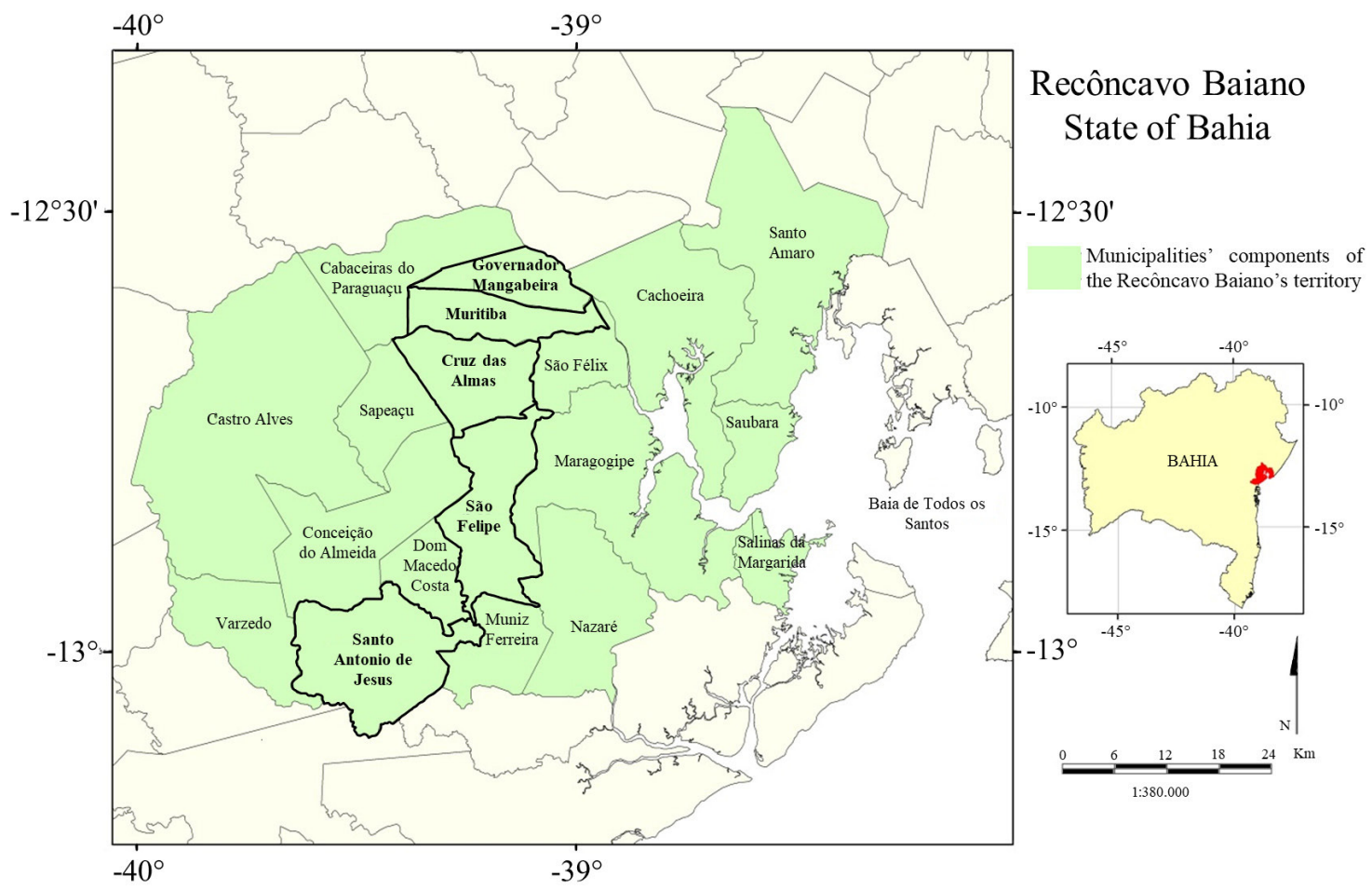

Figure 1. Municipalities' components of the Recôncavo Baiano's identity territory, with emphasis for the sites of the realization of the present study (limits demarcated in bold).Source: Adapted of CODETER (2017) 
Data collection

The data were obtained in the period from April to July 2019 , through interviews applied individually to family citrus growers. The research was conducted in five prominent municipalities of citrus production in the Recôncavo Baiano region: Cruz das Almas, Governador Mangabeira, Muritiba, Santo Antônio de Jesus and São Felipe (Figure 1 and Table 1). The municipalities of Cruz das Almas, Governador Mangabeira and Muritiba, besides
Sapeaçu (not included in the present study) are the most important producers of citrus in the Recôncavo region, besides being in the risk route of introduction of the HLB (LARANJEIRA et al., 2011).

For the determination of the sample size, the information of the Brazilian Institute of Geography and Statistics (IBGE, 2017) was taken into account on the number of establishments producing family farming (24.815 units) in the Recôncavo Baiano's identity territory (Table 2).

Table 1. Indicators of citrus production in five municipalities of the Recôncavo Baiano region, expressed in: production - P (t); area planted or destined for harvest - AP (ha) and average yield - Y (kg.ha-1).

\begin{tabular}{|c|c|c|c|c|c|c|c|c|c|}
\hline \multirow[b]{2}{*}{ Municipality } & \multicolumn{3}{|c|}{ Orange } & \multicolumn{3}{|c|}{ Lemon } & \multicolumn{3}{|c|}{ Tangerine } \\
\hline & $P(t)$ & $\mathrm{AP}(\mathrm{ha})$ & $\begin{array}{c}\mathrm{Y} \\
\left(\mathrm{kg} \cdot \mathrm{ha}^{-1}\right)\end{array}$ & $P(t)$ & AP (ha) & $\begin{array}{c}\mathrm{Y} \\
\left(\mathrm{kg} \cdot \mathrm{ha}^{-1}\right)\end{array}$ & $P(t)$ & AP (ha) & $\begin{array}{c}\mathrm{Y} \\
\left(\mathrm{kg} \cdot \mathrm{ha}^{-1}\right) \\
\end{array}$ \\
\hline Santo Antonio de Jesus & 8150 & 815 & 1000 & - & - & - & 1100 & 250 & 4400 \\
\hline Governador Mangabeira & 5500 & 720 & 7639 & 915 & 170 & 5382 & - & - & - \\
\hline Cruz das Almas & 2450 & 400 & 6125 & 4111 & 750 & 5481 & 10 & 2 & 5000 \\
\hline Muritiba & 1890 & 370 & 5108 & 2250 & 440 & 5114 & - & - & - \\
\hline São Felipe & 1050 & 150 & 7000 & 120 & 16 & 7500 & - & - & - \\
\hline Average & 3808 & 491 & 5374.4 & 1849 & 344 & 5869.3 & 555 & 126 & 4700 \\
\hline
\end{tabular}

Table 2. Number of agricultural establishments with 50 plants and more (Units) (AF1) and with less than 50 existing citrus plants (Units) (AF2).

\begin{tabular}{lrcr}
\hline Municipality & AF1 & AF2 & Total (AF1 + AF2) \\
\hline Cabaceiras do Paraguaçu & 530 & 868 & 1398 \\
Cachoeira & 46 & 1794 & 1840 \\
Castro Alves & 304 & 916 & 1220 \\
Conceição do Almeida & 360 & 323 & 683 \\
Cruz das Almas & 800 & 332 & 1132 \\
Dom Macedo Costa & 53 & 313 & 366 \\
Governador Mangabeira & 827 & 937 & 1764 \\
Maragogipe & 107 & 2467 & 2574 \\
Muniz Ferreira & 25 & 509 & 534 \\
Muritiba & 741 & 834 & 1575 \\
Nazaré & 33 & 576 & 609 \\
Salinas da Margarida & 0 & 32 & 32 \\
Santo Amaro & 38 & 3850 & 3888 \\
Santo Antônio de Jesus & 970 & 2673 & 3643 \\
São Félix & 37 & 531 & 568 \\
São Felipe & 263 & 265 & 528 \\
Sapeaçu & 1347 & 138 & 1485 \\
Saubara & 0 & 89 & 89 \\
Varzedo & 553 & 334 & $\mathbf{2 4 8 1 5}$ \\
Total & $\mathbf{7 0 3 4}$ & $\mathbf{1 7 7 8 1}$ &
\end{tabular}

Source: Adapted of IBGE (2017) 
The statistical software used to scale the sample size was the Statdisk ${ }^{\circledR}$ (TRIOLA, 2018), from the algorithm presented by equation 01 , where it was considered a significance level, $\alpha<0.05$, and an error margin of $10 \%$, due to both the diversity of the nature of the variables involved, as to the possibility of asymmetries in the results of the information collected in this studied scenario. In this condition, the minimum quantity of samples to be collected corresponded to 96 sample units, according to the equation described below:

$$
\text { Sample size }=\frac{\frac{z^{2} * p(1-p)}{e^{2}}}{1+\left(\frac{z^{2} * p(1-p)}{e^{2} * N}\right)}
$$

Where:

$\mathrm{N}=$ size of the population;

$\mathrm{e}=$ error margin (percentage in decimal format); $\mathrm{z}=\mathrm{z}$ score, for $5 \%$ of probability.
With this information, a minimum number of questionnaires was determined to be applied. Hundred and nine interviews were conducted in the five municipalities previously cited. The number of samples was stratified per municipality, considering the number of citrus-producing family establishments. Thus, 51 interviews were conducted (46.8\%), 23 (21.1\%), 20 (18.3\%), 11 (10.1\%) and $4(3.7 \%)$ in Santo Antonio de Jesus, Governador Mangabeira, Cruz das Almas, Muritiba and São Felipe, respectively. The proportion among the number of producer establishments in each municipality and the total of establishments in these municipalities is $42.2 \%, 20.4 \%, 13.1 \%, 18.2 \%$ and $6.1 \%$ (Table 2). It was chosen to increase the number of samples in Santo Antonio de Jesus and Cruz das Almas due to its importance in the production and marketing of citrus seedlings for practically the entire Northeast of Brazil (GIRARDI et al., 2015).

\section{Variables analyzed}

The questionnaires were applied individually in properties of family citrus growers in order to obtain information on the cultivation, cultural practices and management adopted, identification of pests and knowledge about the HLB and its vector (Figure 2).

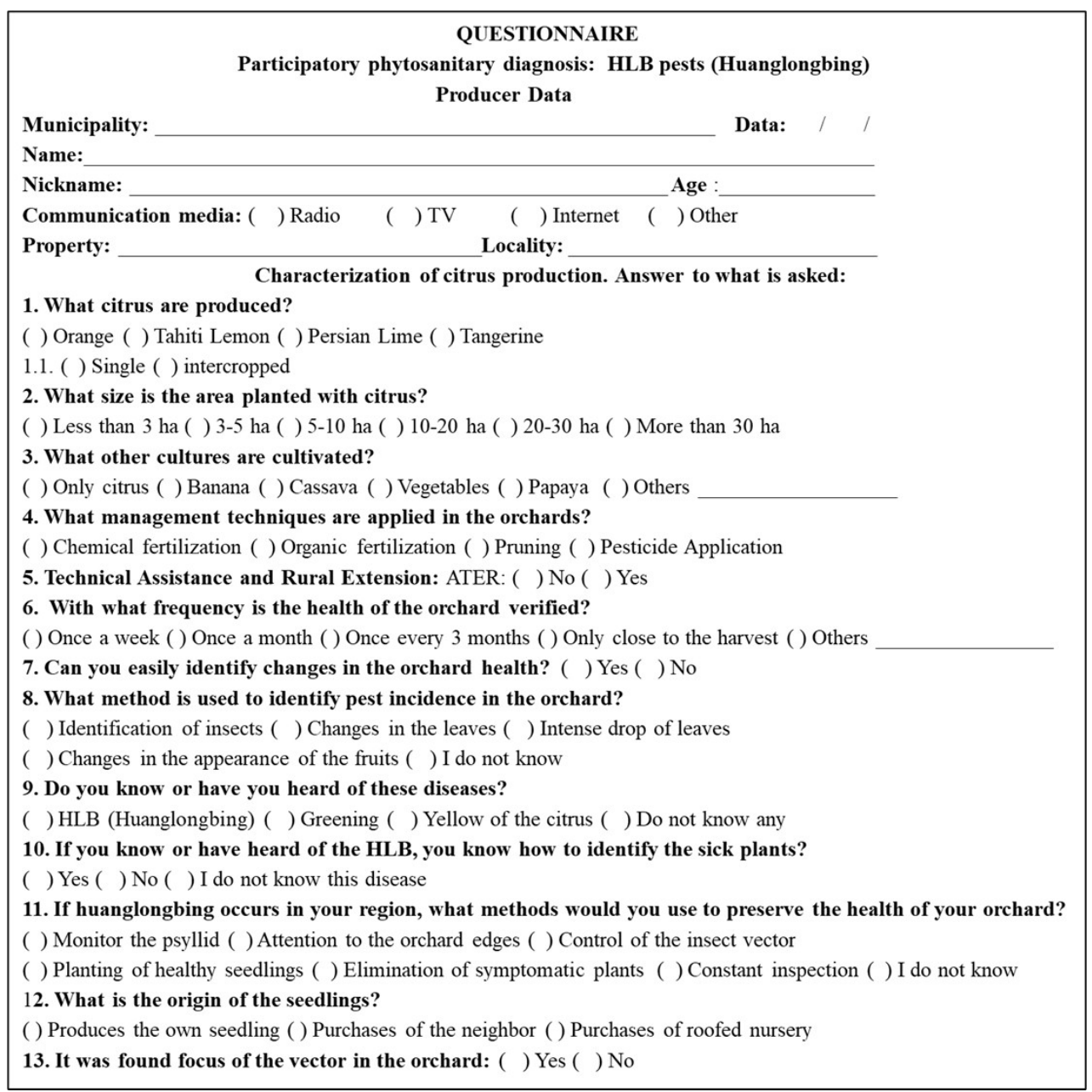

Figure 2. Questionnaire used for the interviews with family citrus growers in municipalities of the Recôncavo Baiano's identity territory. 
The questionnaire contained closed and open questions. To register the perception of the farmers in the knowledge of the HLB, the questionnaire did not have images in order to not influence the responses. Subsequently, at the end of the questionnaire, a folder was used with colored images, in order to facilitate the association and visualization of the psyllid and of the symptoms of the disease.

To characterize the profile of the citrus grower, the analyzed variables were: size of the production area, adoption of management practices (chemical fertilization, organic fertilization, pruning and pesticides application), technical assistance, monitoring in the orchard changes and inspection for identification of the presence of the psyllid in the field (eggs, nymphs or adults). In addition to the questionnaire, survey of the surrounding plants was carried out, in about $1 \%$ of the plants of each orchard, evaluating four branches per plant (preferably with sprouts), positioned in four quadrants of the tree (SULZBACH et al., 2017). The presence or absence of Diaphorina citri was recorded.

Data were analyzed by means of descriptive statistics, using the percentage measure for the cultural tracts, technical assistance, cultivation system (intercropped or single planting), perception of changes in the orchard health, identification of problems related to pests in the orchard, presence of D. citri in the properties, knowledge of the producers about the HLB and origin of the cultivated seedlings.

\section{Results and Discussion}

As the sample universe was formed by family citrus growers, there was a natural direction for the application of questionnaires to small farmers. In fact, the vast majority of the citrus growers interviewed $(77.1 \%)$ had an area lower than or equal to 3 ha; $14.7 \%$ with area of 3.1 to 5 ha; $5.5 \%$, with area of 5.1 to 10 ha; $1.8 \%$, with area of 10.1 to 20 ha and $0.9 \%$, with area of 20 to 30 ha and none of them with area higher than 30 ha.

It is considered a smallholding the area lower than a fiscal module (INCRA, 2020), which is equivalent to 30 ha in the municipalities studied, so all the object areas of the research are classified as smallholdings. The results obtained corroborate with data of Sulzabach et al. (2016), in view of the predominance of family farmers with areas lower than 30 ha, although the percentage of citrus growers with areas lower than 10 ha was of $27 \%$, lower than that obtained in the present study.

\section{Orchard management}

Most of the citrus growers answered that performs chemical fertilization (83\%) and organic fertilization (82\%), corroborating with Sulzbach et al. (2016) (Figure $3 \mathrm{~A})$. However, it is not possible to affirm if they realize the fertilization with technical basis, since the majority (94\%) does not count with technical assistance service and rural extension (ATER) (Figure 3B). Thus, the practice can become inefficient, either by the non-compliance to the plant nutritional needs, resulting in lower productivity, such as by the potential of fertilizer waste by the excess used, in both cases decreasing the income of the producer. In addition, nutritional imbalance can compromise the diagnosis of diseases occurrence such as the HLB, once their symptoms can be confused with the nutritional deficiency (SULZBACH et al., 2017; SANCHES et al., 2018)

In poles of family based citrus growers, technologies should be adopted aiming to the prevention and management of the HLB, being one of them the organic and/or balanced mineral fertilization, with the purpose of anticipating the production before the losses caused by the disease occurs (OLIVEIRA et al., 2018). However, it is noteworthy that in areas with plants infected with HLB, the nutritional management should not supplant the need for eradication of symptomatic plants, under risk of repetition of what happened in Florida, United States of America (SINGERMAN; ROGERS, 2020). In this state, several producers, reluctant in eradicating symptomatic plants, increased the nutritional management aiming to maintain plant productivity, putting at risk the producers that were performing the eradication (SINGERMAN; ROGERS, 2020).

The realization of the pruning was confirmed for $82 \%$ of the responses obtained (Figure $3 \mathrm{~A}$ ), but it is believed that this response was related to the conduction pruning and formation of canopies, since, visually, the plants did not demonstrate that they were conveniently pruned. The phytosanitary pruning is very important to decrease the inoculum sources of pests and rejuvenate the orchard, through the removal of unproductive branches and stimulation to the emission of new shoots in order to balance the production, increase plant longevity and ensure fruit quality (AZEVEDO et al., 2013). Despite very important to the orchard phytosanitary, the pruning is not constituted in a management tool of HLB (ROUSE et al., 2017; VASHISTH; LIVINGSTON, 2019). 


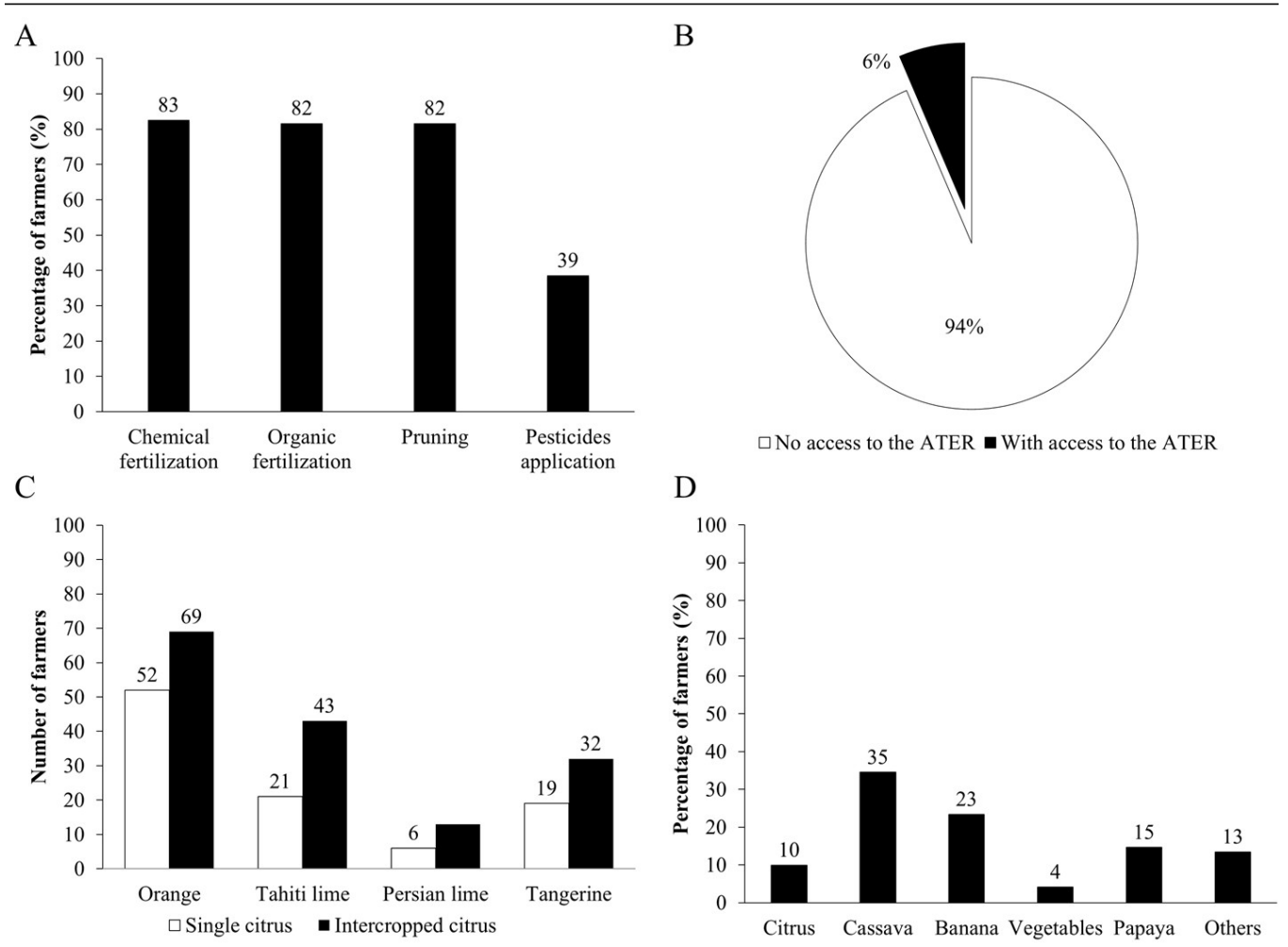

Figure 3. A. Percentage of farmers who perform cultural treatments; B. Percentage of use of Technical Assistance and Rural Extension (ATER); C. Number of farmers who use citrus single and intercropped planting; D. Percentage of producers that cultivate citrus in monoculture or intercropped with other cultures in five municipalities that produce citrus in the Recôncavo Baiano region.

It is observed that, among the managements, the application of pesticides was the only one that obtained limited adoption level (39\%) (Figure 3A), which can reflect the low technological pattern employed in the conduction of the orchards due to the low productivity (SULZBACH et al., 2018; ALVES et al., 2020). For example, for orange, the average productivity in the five municipalities evaluated is $5.374 .4 \mathrm{~kg} \mathrm{ha}^{-1}$ (Table 1), while the baiana orange is of $11.255 \mathrm{~kg} \cdot \mathrm{ha}^{-1}$ (IBGE, 2018), data that do not corroborate the situation of the producers in the state of Rio Grande do Sul, where Sulzbach et al. (2016) found average productivities similar to the average of the state. Consequently, in the imminence of introduction of the HLB, it would represent lower investment in the management of the HLB as discussed by Sulzbach et al. (2017). The population reduction of the vector insect is fundamental to the management of the HLB, and the use of pesticides is the most common control method. And for this, the non-adoption of this strategy or insufficient adoption is considered one of the main factors for the dissemination of the HLB (SULZBACH et al., 2018; ALVES et al., 2020).

\section{Citrus planting and identification of pests}

It is verified that the number of producers that choose for the citrus intercropped planting is on average $37 \%$ higher compared to the citrus single planting (Figure 3C). For analysis of these results, it should be taken into account that the target audience of this research were small producers, most with properties with area below 3 ha.

One very important agricultural practice in citrus cultivation in the conditions of the Reconcavo Baiano is the appropriate management of the soils, either by the reduction of soil movement and turning, as by the maintenance of soil coverage. In this last aspect, it can be cited both the intercropped with other cultures, such as the use of plant coverings, which present as benefits the control of weeds, the maintenance of beneficial organisms and natural pests enemies, besides the increase of microbial biodiversity, improvement of water infiltration in the soil and increase of roots concentration in depth, which contributes to the significant increase in the productivity of the plants (LUCENA et al., 2017). The farmers interviewed claim to make intercropped due to the size of the planting areas. In this intercropped regime, they practice crop rotation in a seasonal way, corresponding to $13.5 \%$, and the main crops are: corn, peanuts, and beans, besides the plants with the highest productive cycle, such as bananas, cassava and papaya (Figure 3D). The most common intercrop is with cassava (35\%), followed by banana $(23 \%)$ and papaya $(15 \%)$. 
The knowledge of the valorization of the intercrop in family production systems of the Recôncavo Baiano can subsidize and strengthen the development of sustainable management programs of the $D$. citri/HLB complex through the "push-pull" technology (YAN et al., 2015; FANCELLI et al., 2018). In this strategy, plants whose semiochemicals are useful in the manipulation of the behavior of insect pests and/or their natural enemies are intercropped (PICKETT et al., 2014). The familiarity of the producers with diversified systems of citrus planting can facilitate the adoption of this technology in the Recôncavo Baiano, in association or not with the biological control.

About $78 \%$ of the farmers claim to be able to perceive visual changes in the orchard (Figure 4A-B), even though they are not able to identify with precision the pest or disease that is installed in the culture. Through this finding, the identification happens first in a visual way by the perception of changes in the appearance of the leaves and subsequently, by the presence of pests (Figure 4B).

In general, the inability to identify in precise manner these pests (Figure 4B) can be associated with the scarcity of information and of technical aid (Figure 3B), making it impossible to apply the application of monitoring programs and integrated management of pests. The consequences of this problem are severe, impairing the decision making regarding the need for control, and can cause failure in the control by the use of inadequate and/or applicable methods for other targets.

As mentioned, the farmers state that the control of several pests that can attack the orchard is limited by some factors, such as high cost of acquiring pesticides and implementation of phytosanitary treatments that increase the production cost in a significant way, which is corroborated by several authors when they refer to small producers (SULZBACH et al., 2016, 2017, ALVES et al., 2020).

The monitoring of the orchard is of paramount importance, because it enables the observation of pests and its degree of infestation. The decision making to apply or not the insecticide should take into account the inspection and the evaluation of the presence of the insect pest and of the natural enemies (AZEVÊDO, 2003). According to the interviews, the farmers ensure that they perform, in their majority, periodic inspection in the orchard at least once a week, which indicates the possibility of rapid observation of the changes (Figure 4C).

The HLB is considered as one of the great phytosanitary problems of the citrus culture and its dissemination is mainly through the vector insect, the psyllid D. citri (AUBERT, 1987; HALBERT; MANJUNATH, 2004; BOVÉ, 2006). In the present research, the occurrence of psyllids was detected in $6 \%$ of the properties visited, in the municipalities of Cruz das Almas and Governador Mangabeira (Figure 4D). Taking into account that the last interviews were conducted in the months of June and July, corresponding to periods with low temperatures, were not found new sprouts in the plants, despite the high rainfall index, which may have restricted the possibility of finding psyllid eggs and nymphs. The presence of young sprouts and leaves is fundamental not only to the regulation of the population of the insect (YANG et al., 2013), since they are constituted in the preferential niche of oviposition of the insect adults and serve as a food source for newly hatched nymphs and in the early stages of development. The presence of young sprouts is also associated with the higher acquisition efficiency of $\mathrm{Ca}$. L. asiaticus in places where the disease occurs (SÉTAMOU et al., 2016).

In the studied region, it was possible to observe that there is no knowledge about the citrus HLB pathosystem among citrus growers (Figure 5A), increasing the risk of late identification and subsequent advance of the pest. It was also observed that $21 \%$ of the interviewees affirmed to know the "yellow of the citrus". After more questions, it was noticed that there is an misconception in the recognition, occurring the confusion of the symptoms with the Citrus Variegated Chlorosis, whose symptoms are similar (SANTOS FILHO et al., 2010).

The citrus growers who claimed to have heard about the disease were producers of seedlings, which commercialize for local producers (Figure 5A-B). It is important to mention that the State Ordinance 243/2011, instituted by the State Agency of Agricultural Defense (ADAB), provides, among other subjects, on the transition of the seedlings production system of open sky to the roofed environment, and these seedlings producers are not in accordance with the provisions of the state legislation.

The practice of using propagative material (seedlings, buds, graft) produced at "open sky" (GIRARDI et al., 2015), regardless of being produced by themselves, or by third parties, is configured in a great fragility of the Bahia citrus producer.

This fragility is based in four aspects: it is an incurable disease and is not available of any commercial material with resistance to the bacteria; pathosystem that has an extremely efficient vector insect in the acquisition, replication and dissemination of the bacteria; disease that has high latency time; and in the inability of the citrus growers to recognize the symptoms of the citrus HLB (SULZBACH et al., 2017; 2018).

Considering that the HLB is a critical disease to the citrus agribusiness and that configures an epidemic of rapid progress and of high management cost, it is necessary to develop a broad awareness campaign for the producers. 
A

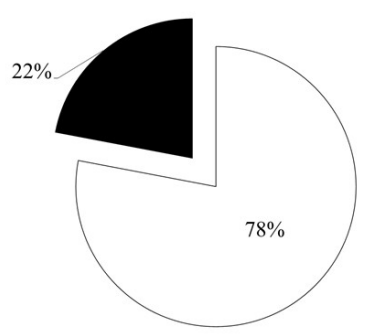

$\square$ Easily identifies phytosanitary changes

$\mathrm{C}$

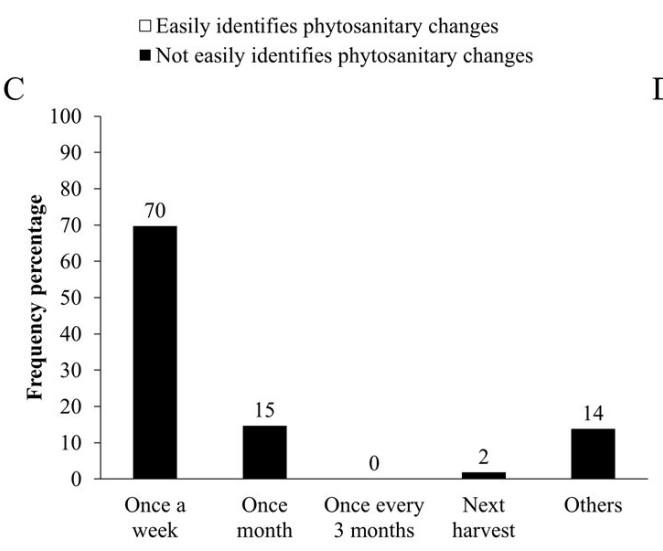

B

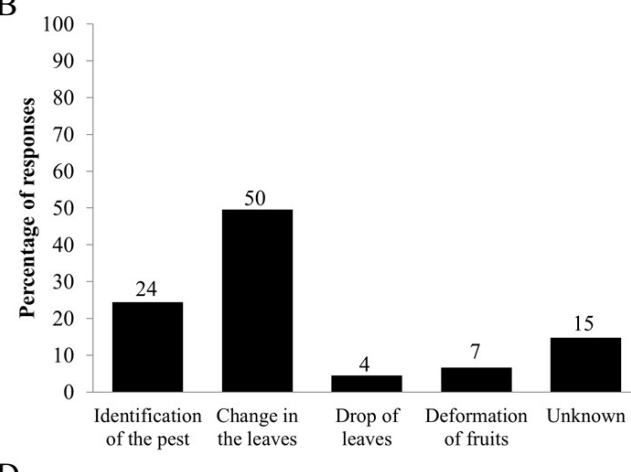

D

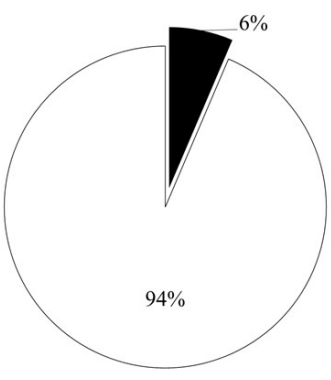

- Presence of the insect vector $\square$ Absence of the insect vector

Figure 4. A. Facility in the perception of phytosanitary changes of the orchard by the producers; B. Perception of the farmers face the changes induced by pests; C. Frequency of phytosanitary verification of the orchards; D. Incidence (\%) of Diaphorina citri in orchards in five municipalities producing citrus in the Recôncavo Baiano.

A

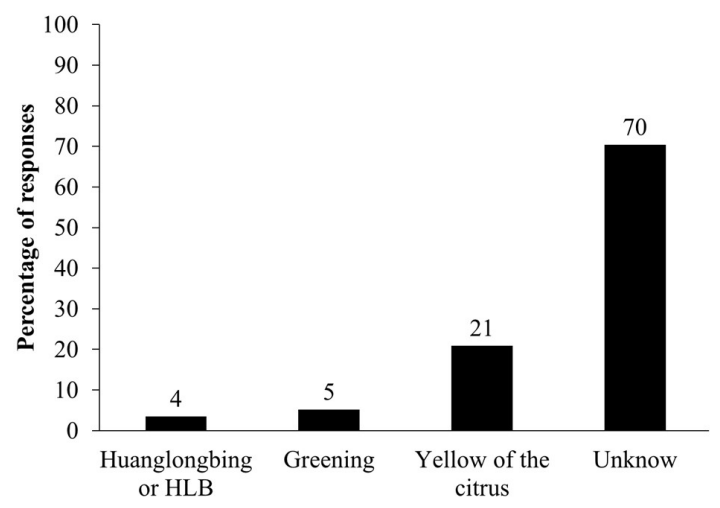

$\mathrm{B}$

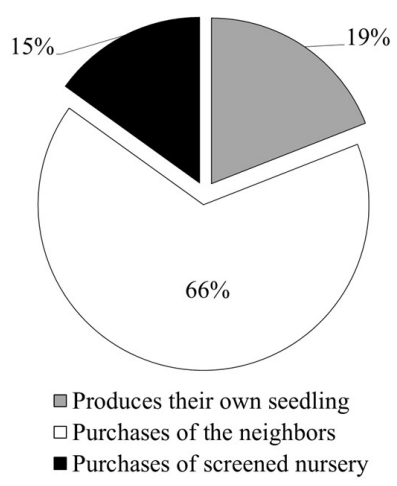

Figure 5. A. Percentage of citrus growers acquaint with the terminology of the citrus Huanglongbing: HLB, greening, yellow of the citrus; B. Origin of the propagative material (seedlings) used in the formation of new orchards and in the replacement of areas implemented in five citrus producing municipalities in the Recôncavo Baiano region.

Considering that the management of the HLB requires the adoption of measures in wide, integrative and articulated area, the lack of knowledge of the productive sector on this disease is disturbing for the segment of the agricultural defense (BASSANEZI et al., 2010; SULZBACH et al., 2017; OLIVEIRA et al., 2018), despite the great commitment in disciplining the entry, the transit and the trade of propagative material in the state of Bahia, as well as monitor the population of the vector insect and the invasion of the bacterium (OLIVEIRA et al., 2013).
It is suggested that the Bahia agricultural segment organizes a public policy able to instrumentalize the agricultural defense organ for an effective surveillance; empower the citrus producers with knowledge about the citrus HLB; consolidate the production system of propagative material in a protected environment; and encourage the organization of the productive chain under the principles of associativism and cooperativism (SULZBACH et al., 2018). 


\section{Conclusions}

This study evidences that, as a rule, the citrus producers from municipalities of the Recôncavo Baiano region are not able to identify the symptoms of the diseases and pests that compromise the health of the orchard. In addition, in their majority, they are unaware of the HLB, its severity and association with the citrus psyllid.

It is noticed the need to aware the citrus growers of the Recôncavo Baiano's identity territory on the severity of the HLB and the recognition of the biological association between this disease and the insect vector Diaphorina citri.

The reach of this level of information can provide decision-making that will optimize the interventional strategies of the State, especially those that refer to the principles of health education and to the rules of surveillance of plants transit.

\section{References}

ALVES, K.S.; DO CARMO, L.H.M.; DEL PONTE, E.M. Spatiotemporal spread of huanglongbing in commercial citrus orchards of Minas Gerais, Brazil. Tropical Plant Pathology, Brasília, DF, v.45, p.668-679, 2020.

AUBERT, B. Trioza erytreae Del Guercio and Diaphorina citri Kuwayama (Homoptera: Psyllidae), the two vectors of citrus greening disease: biological aspects and possible control strategies. Fruits, Paris, v.42, p.149-162, 1987.

AZEVÊDO, C.L.L. Sistema de produção de citros para o Nordeste: pragas. Cruz das Almas: Embrapa Mandioca e Fruticultura, 2003. (Sistema de Produção, 16). Disponível em: https://sistemasdeproducao.cnptia. embrapa.br/FontesHTML/Citros/CitrosNordeste/pragas. htm. Acesso em: 17 nov. 2017.

AZEVEDO, F.A.; LANZA, N.B; SALES, C.R.G; SILVA, K.I; BARROS, A.L; NEGRI, J.D. Poda na citricultura. Citrus Research \& Technology, Cordeirópolis, v.34, n.1, 17-30, 2013.

BASSANEZI, R.B.; LOPES, S.A.; BELASQUE JÚNIOR, J.; SPÓSITO, M.B.; YAMAMOTO, P.T.; MIRANDA, M.P. de; TEIXEIRA, D. do C.; WULFF, N.A. Epidemiologia do huanglongbing e suas implicações para o manejo da doença. Citrus Research \& Technology, Cordeirópolis, v.31, n. 1, 11-23, 2010.

BASSANEZI, R.B.; LOPES, S.A.; MIRANDA, M.P.de; WULFF, N.A.; VOLPE, H.X.L.; AYRES, A.J. Overview of citrus huanglongbing spread and management strategies in Brazil. Tropical Plant Pathology, Brasília, DF, v.45, p.251-264, 2020.
BELASQUE JR., J.; BERGAMIN FILHO, A.; BASSANEZI, R.B.; BARBOSA, J.C.; FERNANDES, N.G.; YAMAMOTO, P.T.; LOPES, S.A.; MACHADO, M.A.; LEITE JR., R.P.; AYRES, A.J.; MASSARI, C.A. Base científica para erradicação de plantas sintomáticas de assintomáticas de Huanglongbing (HLB, greening) visando o controle efetivo da doença. Tropical Plant Pathology, Brasília, DF, v.34, p.137-145, 2009.

BOVÉ, J.M. Huanglongbing: a destructive, newlyemerging, century-old disease of citrus, Journal of Plant Pathology, Pisa, v.88, n.1, p.7-37, 2006.

CODETER - Colegiado de Desenvolvimento Territorial. PTDRSS do Recôncavo: plano territorial de desenvolvimento rural, sustentável e solidário. Cruz das Almas: Universidade Federal do Recôncavo da Bahia, 2017. 55p.

CDA - Coordenadoria de Defesa Agropecuária do Estado de São Paulo. Dados da citricultura paulista. 2019. Disponível em: https://www.defesa.agricultura.sp.gov. br/www/gdsv/index.php?action=dadosCitriculturaPaulis ta. Acesso em: 15 out. 2019.

DAMSTEEGT, V.D.; POSTNIKOVA, E.N.; STONE, A.L.; KUHLMANN, M.; WILSON, C.; SECHLER, A.; SCHAAD, N.W.; BRLANSKY, R.H.; SCHNEIDER, W.L. Murraya paniculata and related species as potential hosts and inoculum reservoirs of 'Candidatus Liberibacter asiaticus', causal agent of Huanglongbing. Plant Disease, Saint Paul, v.94, p.528-533, 2010.

DE CARLI, L.F.; MIRANDA, M.P.; VOLPE, H.X.L.; ZANARDI, O.Z.; VIZONI, M.C.; MARTINI, F.M.; LOPES, J.A.P. Leaf age affects the efficacy of insecticides to control Asian citrus psyllid, Diaphorina citri (Hemiptera: Liviidae). Journal of Applied Entomology, Berlin, v.142, p.689-695, 2018.

FANCELLI, M.; BORGES, M.; LAUMANN, R.A.; PICKETT, J.A.; BIRKETT, M.A.; BLASSIOLIMORAES, M.C. Attractiveness of host plant volatile extracts to the Asian citrus psyllid, Diaphorina citri, is reduced by terpenoids from the non-host cashew. Journal of Chemical Ecology, Dordrecht, v.44, n.4, p.397-405, 2018.

FERREIRA, M. da C. Aplicação de produtos fitossanitários e calibração de pulverizadores para a cultura dos citros. In: ANDRADE, D.J. de; FERREIRA, M. da C.; MARTINELLI, N.M. (ed). Aspectos da fitossanidade em citros. Jaboticabal: Cultura Acadêmica, 2014. cap.9, p.245-265. 
GIRARDI, E.A.; OLIVEIRA, J.R.P.; SILVA, A.C.M.; BARBOSA, D.H.S.G.; SANTOS FILHO, H.P.; VILARINHOS, A.D.; SOARES FILHO, W.S.S.; PASSOS, O.S. Atualização do diagnóstico sobre sistema de produção de mudas de citros no Recôncavo da Bahia. Cruz das Almas: Embrapa Mandioca e Fruticultura, 2015. 67p. (Documentos, 213).

GOTTWALD, T.R.; DA GRAÇA, J.V.; BASSANEZI, R.B. Citrus huanglongbing: the pathogen and its impact. Plant Health Progress, Saint Paul, v.8, n.1, p.31, 2007.

GRAÇA, J.V.; DOUHAN, G.W.; HALBERT, S.E.; KEREMANE, M.L.; LEE, R.L.; VIDALAKIS, G.; ZHAO, H. Huanglongbing: an overview of a complex pathosystem ravaging the world's citrus. Journal of Integrative Plant Biology, Beijing, v.58, n.4, p.373-387, 2016.

GRAFTON-CARDWELL, E.; STELINSKI, L.L.; STANSLY, P.A. Biology and management of Asian citrus psyllid, vector of the huanglongbing pathogens. Annual Review of Entomology, Stanford, v.58, p.413-432, 2013.

HALBERT, S.E.; MANJUNATH, K.L. Asian citrus psyllids (Sternorrhyncha: Psyllidae) and greening disease of citrus: a literature review and assessment of risk in Florida. Florida Entomologist, Gainesville, v.87, n.3, p.330-353, 2004.

HALL, D.G.; RICHARDSON, M.L.; AMMAR, E.; HALBERT, S.E. Asian citrus psyllid, Diaphorina citri, vector of citrus huanglongbing disease. Entomologia Experimentalis et Applicata, Dordrecht, v.146, p.207223, 2012.

IBGE - Instituto Brasileiro de Geografia e Estatística. Censo Agropecuário 2017: resultados definitivos. Rio de Janeiro: SIDRA, 2017. Disponível em: https://sidra. ibge.gov.br/tabela/6955\#notas-tabela. Acesso em: $27 \mathrm{dez}$. 2020.

IBGE - Instituto Brasileiro de Geografia e Estatística. Produção Agrícola Municipal. 2018. Rio de Janeiro: SIDRA. Disponível em: https://sidra.ibge.gov.br/ tabela/1613. Acesso em: 22 ago. 2020.

INCRA - Instituto Nacional de Colonização e Reforma Agrária. Classificação dos imóveis rurais. 2020. Disponível em: https://antigo.incra.gov.br/pt/modulofiscal.html. Acesso em: 14 mar. 2021.
LARANJEIRA, F.F.; SILVA, S.X.B.; ANDRADE, E.C.; NASCIMENTO, A.S.; ALMEIDA, D.de O.; MAGALHÃES, É.; NUNES, C.C.S.; MOTTA, R.S.; BOMFIM, R.C.L.;ALMEIDA, M.A.C.C.de. Mapeamento de hospedeiros suscetíveis ao HUANGLONGBING dos citros no Recôncavo Baiano. Cruz das Almas: Embrapa Mandioca e Fruticultura, 2011.20p. (Boletim de Pesquisa e Desenvolvimento, 55).

LOPES, S.A.; FRARE, G.F..; CAMARGO, L.E.A.; WULFF, N.A.; TEIXEIRA, D.C.; BASSANEZI, R.B.; BEATTIE, G.A.C.; AYRES, A.J. Liberibacters associated with orange jasmine in Brazil: Incidence in urban areas and relatedness to citrus liberibacters. Plant Pathology, New York, v.59, p.1044-1053, 2010.

LUCENA, C.C. de; CARVALHO, J.E.B. de; XAVIER, F.A. da S. Manejo de coberturas vegetais em pomares de citros nos tabuleiros costeiros. Cruz das Almas: Embrapa Mandioca e Fruticultura, 2017. 48p.

OLIVEIRA., R.P. de; GIRARDI, E.A.; SULZBACH, M.; SCHWARZ, S.F.; CARVALHO, F.L.C.; BERNARD, L. de M. Tecnologias para prevenção e manejo do Huanglongbing (HLB) em polos de citricultura de base familiar. Pelotas: Embrapa Clima Temperado, 2018.26 p. (Documentos, 471).

OLIVEIRA, J.M.C.; NASCIMENTO, A.S.; MIRANDA, S..H G.; BARBOSA, C.J.; LARANJEIRA, F.F. Estimating the economic impact of an eventual introduction of huanglongbing (HLB) in the state of Bahia, Brazil. Revista Brasileira de Fruticultura, Jaboticabal, v.35, n.3, p.755-762, 2013.

PALMIERI, F.G.; CAPPELLO, F.P.; BOTEON, M.; PAGLIUCA, L.G. Caminhos da citricultura no pós-crise. Hortifrut Brasil, Piracicaba, n.14, p.10-19, 2016.

PICKETT, J.A.; WOODCOCK, C.M.; MIDEGA, C.A.O.; KHAN, Z.R.Push-pull farming systems. Current Opinion in Biotechnology, London, v.26, p.125-132, 2014.

REZENDE, J. de O.Um olhar sobre a citricultura do Estado da Bahia. Bahia Agrícola, Salvador, v.9, n.1, p.72-93, 2011. Disponível em: http://www.seagri.ba.gov. br/sites/default/files/4_socioeconomia05v9n1.pdf.Acesso em: 15 mai. 2019.

ROUSE, R.E.; OZORES-HAMPTON, M.; ROKA, F.M.; ROBERTS, P. Rehabilitation of Huanglongbing-affected citrus trees using severe pruning and enhanced foliar nutritional treatments. HortScience, Alexandria, v.52, p.972-978, 2017. 
SANCHES, M.M.; WULFF, N.A.; SILVA, M.R.L.; LEITE JR, R.P.; FERREIRA, E.A.; dos SANTOS, J.F.; SILVA, M.L.; ANGARTEN, M.B.de O.; ISHIDA, A.K.N.; OLIVEIRA, R.P.de; LUCCAS, B.E.G.de; CARBONARI, J.J.; MARTINS, O.M. Levantamento de huanglongbing (HLB) em citros no Brasil e diagnose dos agentes etiológicos. Brasília (DF): Embrapa Recursos Genéticos e Biotecnologia, 2018.21p. (Boletim de Pesquisa e Desenvolvimento, 337).

SANTOS FILHO, H.P.; BARBOSA, C. de J.; LARANJEIRA, F.F.; SILVA, S.X. de B. Clorose variegada dos citros: ameaça a citricultura do Recôncavo Sul. Cruz das Almas: Embrapa Mandioca e Fruticultura, 2010. (Citros em foco, 34).

SÉTAMOU, M.; ALABI, O.J.; KUNTA, M.; JIFON, J.L.; DA GRAÇA, J.V. Enhanced acquisition rates of 'Candidatus Liberibacter asiaticus' by the Asian citrus psyllid (Hemiptera: Liviidae) in the presence of vegetative flush growth in citrus. Journal of Economic Entomology, Lanham, v.109, n.5, p.1973-1978, 2016.

SHIBATA, R.T.; REZENDE, J. de O.; SOUZA, L .da S. Citricultura nos Estados da Bahia e Sergipe. Bahia Agrícola, Salvador, v.9, n.3, p.48-57, 2014.

SINGERMAN, A.; ROGERS, M.E. The economic challenges of dealing with citrus greening: the case of Florida. Journal of Integrated Pest Management, Lanham, v.11, n.3, p.1-7, 2020.

SULZBACH, M., OLIVEIRA, R.P.de; GIRARDI, E.A.; BASSANEZI, R.B.; LARANJEIRA, F.F.; SCHWARZ, S.F. Risk analysis of introduction and spread of huanglongbing in citrus groves in Rio Grande do Sul, Brazil. Tropical Plant Pathology, Brasília, DF, v.43, p.49-58, 2018.
SULZBACH, M.; OLIVEIRA, R.P. de; GIRARDI, E.A.; SCHWARZ, S.F.; BERTOLINI, E.; SCHNEIDER, L.A.; GONZATTO, M.P. Huanglongbing (HLB) dos citros e estratégias de manejo visando prevenção e controle. Pelotas: Embrapa Clima Temperado, 2017. 36 p. (Documentos, 450).

SULZBACH, M.; OLIVEIRA, R.P. de; WAQUIL, P.D.; GIRARDI, E.A.; GONZATTO, M.P.; BÖETTCHER, G.N.; SCHWARZ, S.F. Characterization of citrus farms production systems used in Rio Grande do Sul, Brazil. Citrus Research \& Technology, Cordeirópolis, v.37, n.1, p 1-9, 2016.

TRIOLA, M.F. STATDISK: triola statistics series. 13th ed. London: Pearson, 2018.

VASHISTH, T.; LIVINGSTON, T. Assessment of pruning and controlled release fertilizer to rejuvenate Huanglongbing-affected sweet orange. HortTechnology, Alexandria, v.29, p.933-940, 2019.

YAN, H.; ZENG, J.; ZHONG, G. The push-pull strategy for citrus psyllid control. Pest Management Science, Medford, v.71, n.7, p.893-896, 2015.

YANG, Y.; BEATTIE, G.A.C.; SPOONER HART, R.N.; HUANG, M.; BARCHIA, I.; HOLFORD, P. Influences of leaf age and type, non host volatiles, and mineral oil deposits on the incidence, distribution, and form of stylet tracks of Diaphorina citri. Entomologia Experimentalis et Applicata, Dordrecht, v.147, n.1, p.33-49, 2013.

ZULIAN, A.; DÖRR, A.C.; ALMEIDA, S.C. Citricultura e agronegócio cooperativo no Brasil. Revista Eletrônica em Gestão, Educação e Tecnologia Ambiental, Santa Maria, v.11, n.11, p.2290-2306, 2013. 